\title{
mcr-1 Gene in Latin America: How Is It Disseminated Among Humans, Animals, and the Environment?
}

\author{
Silvia Adriana Mayer Lentz ${ }^{1,2}$, Tanise Vendruscolo Dalmolin ${ }^{3}$, Afonso Luís Barth ${ }^{4}$ and \\ Andreza Francisco Martins ${ }^{1,2,4 *}$ \\ 1 Programa de Pós Graduação em Microbiologia Agrícola e Do Ambiente, Universidade Federal Do Rio Grande Do Sul, Porto \\ Alegre, Brazil, ${ }^{2}$ Laboratório de Microbiologia Aplicada, Instituto de Ciências Básicas da Saúde, Universidade Federal Do Rio \\ Grande Do Sul, Porto Alegre, Brazil, ${ }^{3}$ Faculdade de Saúde, Departamento de Farmácia, Universidade de Brasília (UnB), \\ Brasilia, Brazil, ${ }^{4}$ Laboratório de Pesquisa em Resistência Bacteriana (LABRESIS), Hospital de Clínicas de Porto Alegre, Porto \\ Alegre, Brazil
}

Keywords: $m c r-1$ gene, IncX4 plasmid type, colistin resistance, Latin America, antimicrobial resistance

\section{INTRODUCTION}

In the last decade, polymyxins have been reintroduced in the therapeutic arsenal to treat severe infections by carbapenem-resistant Enterobacterales. At that time, reports of polymyxin resistance

OPEN ACCESS

Edited by: Swaminath Srinivas,

University of lllinois at Urbana-Champaign, United States

Reviewed by:

Ridwan Bin Rashid,

State University of Bangladesh, Bangladesh

*Correspondence: Andreza Francisco Martins andrezafm20@gmail.com

Specialty section:

This article was submitted to Planetary Health,

a section of the journal Frontiers in Public Health

Received: 02 January 2021 Accepted: 22 February 2021 Published: 07 May 2021

Citation: Lentz SAM, Dalmolin TV, Barth AL and Martins AF (2021) mcr-1 Gene in Latin America: How Is It Disseminated Among Humans, Animals, and the

Environment?

Front. Public Health 9:648940.

doi: 10.3389/fpubh.2021.648940 were all due to chromosomal mutations (1). These mechanisms included (i) modifications of the lipopolysaccharides (LPSs) moiety via the addition of cationic groups; (ii) mutations that lead to the loss of the LPS; (iii) porin mutations and overexpression of efflux pump systems; (iv) overproduction of capsular polysaccharide (CPS) in some Gram-negative bacteria (GNB) that hide the polymyxin-binding sites and the release of CPS-trapping polymyxins; and (v) enzymatic inactivation of polymyxins (2). Although some chromosomal resistance mechanisms have been studied since the 1960's, it was in the late 1990's, after the reintroduction of polymyxins in the therapeutic arsenal, that this problem became more important (3). In fact, this information is supported by the first report of colistin resistance among Acinetobacter baumannii clinical isolates from the Czech Republic in 1999 and Klebsiella pneumoniae from Athens in 2004 (4).

However, in 2015, the $m c r-1$ gene, associated with IncI2-type plasmid, was identified in Escherichia coli resistant to colistin obtained from food animals and humans in China (1). This finding promoted a great concern in the international scientific community since the last therapeutic option to treat serious infections by multidrug-resistant GNB could be exhausted. With the horizontal transfer, the rapid spread of the $m c r-1$ gene would be inevitable.

The mor-1 gene carried by different plasmid types has already been identified in all five continents from different sources and hosts $(1,5)$. Surprisingly, Shen and colleagues, in a retrospective study, characterized the early occurrence of the $m c r-1$ gene in chicken isolates from 1980's (6).

So far, a total of 10 different variants (7) of the $\mathrm{mor}$ gene have been described mainly among the Enterobacterales, but with the $m c r-1$ gene remaining the most prevalent (1). To date, the sequences of $30 \mathrm{mcr}-1$ mutations ( $m c r-1.2$ to $m c r-1.30$ ) have already been deposited in the GenBank database, differing from $m c r-1$ by one or few amino acids. Besides that, $10 \mathrm{mcr}$ gene variants $(\mathrm{mcr}-1$ to $\mathrm{mcr}$ 10) were deposited, with amino acid identity ranging from 31 to $83 \%$ (8). These variants were identified at the beginning in Enterobacterales isolates, including E. coli ( $m c r-1, m c r-2$, and $m c r-$ 3 genes), Salmonella enterica ( $m c r-4, m c r-5$ and $m c r-9$ genes), K. pneumoniae ( $m c r-7$ and $m c r-8$ genes), and Enterobacter roggenkampii (mcr-10 gene). The exception is due to $m c r-6$ gene that was first identified in Moraxella spp. After that, some variants were identified in non-fermenter 
Gram-negative rods, as Acinetobacter spp. (mcr-1 and $m c r-4)$ and Pseudomonas spp. ( $m c r-1$ only) $(9,10)$.

In general, the isolates carrying $\mathrm{mcr}$ genes were first isolated from animals such as pigs $(m c r-1, m c r-2, m c r-3, m c r-4, m c r-6$, and $m c r-8$ genes) and chickens ( $m c r-5$ and $m c r-7$ genes), but $m c r-9$ and $m c r-10$ genes were identified, for the first time, from human patients (8).

\section{EPIDEMIOLOGY OF POLYMYXIN RESISTANCE}

The resistance to polymyxins was attributed mainly to chromosomal mutations and is rare in human clinical isolates (0.67-1.6\%) (11). Nevertheless, this differs among bacteria species, being higher in $K$. pneumoniae and A. baumannii (20-80\%) (4) in contrast to lower rates in E. coli (0.2-0.6\%) (11).

The polymyxin resistance rate associated to plasmid, as $\mathrm{mcr}$ 1 , is also low in humans $(\sim 1 \%)$ (4). On the other hand, according to a large US surveillance study, the association between $m c r-1$ and other antibiotic resistance genes, such as extended-spectrum $\beta$-lactamase (ESBL) and carbapenemases, may reach $32 \%$ of prevalence in K. pneumoniae (11). Regarding the mortality associated with infections caused by colistinresistant isolates in humans, the rate is variable, and it is higher in critically ill patients $(30-37 \%)$ including those previously exposed to colistin (4). The mortality rate may reach $100 \%$ in patients with nosocomial infections caused by pan-drugresistant K. pneumoniae.

It is important to emphasize that the prevalence of $m c r-1$ gene is higher among production animals, mainly in pig and chicken isolates (5). The data show colistin resistance rates of $\sim 70 \%$ in E. coli isolates from China and $\sim 90 \%$ among Enterobacterales in some European countries (8). So, these data corroborate with the scientific evidence that the worldwide spread of the $m c r-1$ gene is mainly associated with the large amounts of colistin use in production animals, and its emergence is a particular threat to public health as colistin is considered the last-resort antimicrobial for treatment of severe human infections, and its use in livestock production contributes to emerging resistance globally (1).

\section{mcr-1 IN LATIN AMERICA}

In Latin America, a systematic review analysis showed that the prevalence of $m c r-1$ gene is higher in isolates from animals $(8.7 \%)$ than in food $(5.4 \%)$ and humans $(2.0 \%)$ (12). To the best of our knowledge, the first reports of $m c r-1$ gene in Latin America dated from July and October 2012 when this gene was identified in $E$. coli isolates from two inpatients in different hospitals in Argentina (Table 1) (13). Patients presented neurological disease and diabetes, and the mcr-1-positive isolates were obtained from blood and urine, respectively. In this study, the authors evaluated the presence of the $m c r-1$ gene in 87 colistin-resistant clinical human isolates from 2008 to 2016 (28 E. coli, 19 K. pneumoniae, 36 of other members of the Enterobacterales, and 4 non-fermenter Gram-negative rods), and nine isolates of E. coli were $m c r-1$ positive. These isolates were associated with human infections, mainly in males, and the average age of the patients was 68.5 years. All $m c r-1$-positive E. coli isolates were genetically unrelated as determined by pulsed-field gel electrophoresis, and the resistance mechanism was horizontally transferable by conjugation (13). Still, in 2012, other studies reported $m c r-1$ harboring $E$. coli recovered from Kelp Guls in Argentina (14) and from swine in Brazil (Table 1) (15).

Since 2012, the $m c r-1$ gene has already been identified in bacteria from humans, animals, animal food products, and environmental sources in different countries in Latin America, including Brazil (15), Bolivia (16), Colombia (17), Chile (18), Uruguay (19), Paraguay (20), Peru (21), Mexico (22), Venezuela (23), and Ecuador (24). Brazil is the country with the highest number of $m c r$-1-positive bacteria reported in Latin America mainly from bacterial isolates obtained from poultry rectal swabs (15) (Table 1).

It is important to consider that Brazil is the fourth largest pork producer and exporter and the largest chicken meat exporter in the world, which could contribute to the high prevalence of the $m c r-1$ gene in this country (25). As in other countries, the colistin was extensively used in Brazil as a growth promoter for many years. In 2016, the government published restrictions on the use of colistin in animal production $(1,26)$, which came into force in 2018. However, the use of colistin to treat or prevent infections in veterinary medicine including animal productions is still allowed.

E. coli is the most common species harboring the mor1 gene in Latin America countries. However, many other Enterobacterales members such as K. pneumoniae, Salmonella spp., Citrobacter spp., and Enterobacter spp. were also reported as positive for the $m c r-1$ gene $(17,27)$. In addition to $m c r-1$, other variants of the gene were reported rarely in Latin America, such as $m c r-3, m c r-5, m c r-7$, and $m c r-9(28-30)$.

\section{GENETIC CONTEXT AND DISSEMINATION OF $m c r-1$ GENE}

E. coli isolates harboring $m c r-1$ gene belong to different sequence types (STs) $(31,32)$ (Table $\mathbf{1}$ ), indicating that the dissemination of the $m c r-1$ gene is associated with different clonal strains (1). Loayza-Villa and colleagues investigated the relationship between an $E$. coli carrying $m c r-1$ recovered from the gastrointestinal tract of a boy and an mcr-1-positive E. coli from fecal samples and rectal/cloacal swabs from his domestic animals. E. coli strains from domestic animals and from the boy were different; however, all plasmids harboring the $m c r-1$ gene shared 90\% nucleotide identity and a highly conserved backbone, supporting the idea of horizontal dissemination of the $m c r-1$ gene (32).

In Latin America, the E. coli belonging to CC10 clonal complex, known as the largest human clonal complex, was the most reported in previous studies, including the ST744 and ST10 $(1,17,22,33)$. E. coli CC10 strains are widely disseminated among humans, animals, meat products, and environmental sources $(34,35)$ and are designated as multidrug-resistant strains carrying frequently ESBL, among others $(5,31)$.

The $m c r-1$ gene is carried by a wide range of conjugative and non-conjugative plasmid types, including IncX3, IncX4, an 
TABLE 1 | Summary of mainly studies reporting $m c r-1$ gene in Latin America.

\begin{tabular}{|c|c|c|c|c|c|c|c|c|}
\hline $\begin{array}{l}\text { Period of } \\
\text { the study }\end{array}$ & Country & Source of Isolate & $\begin{array}{l}\text { Total Isolates } \\
\text { (mcr-carried) }\end{array}$ & Species & Plasmid Type & Sequence Type (ST) & Genetic Context & References \\
\hline 2000-2016 & Brazil & $\begin{array}{l}\text { Fecal samples-chicken and } \\
\text { swine (Production Animals) }\end{array}$ & $515(16)$ & E. coli & - & - & - & (15) \\
\hline 2002-2016 & Colombia & $\begin{array}{l}\text { Urine vaginal secretion blood } \\
\text { stool tissue right toe leg } \\
\text { secretion abdomen abscess } \\
\text { (Human) }\end{array}$ & $513(12)$ & $\begin{array}{l}\text { E. coli } \\
\text { S. enterica Typhimurium } \\
\text { K. pneumoniae }\end{array}$ & $\begin{array}{l}\text { IncP-1 IncFIII IncHl1 } \\
\text { IncH }\end{array}$ & $\begin{array}{l}\text { E. coli (ST10, ST37, ST101, } \\
\text { ST744, ST1263, ST3056, } \\
\text { and ST6627) } \\
\text { S. Typhimurium (ST34) } \\
\text { K. pneumoniae (ST307) }\end{array}$ & $\begin{array}{l}\text { ISApl1-mcr-1-pap2 (IncP-1) } \\
\text { mcr-1-pap2 (IncP-1) }\end{array}$ & (17) \\
\hline 2008-2016 & Argentina & $\begin{array}{l}\text { Urine, blood, abdomen, } \\
\text { abscess, bone (Human) }\end{array}$ & $87(9)$ & E. coli & - & - & - & (13) \\
\hline 2012 & Argentina & $\begin{array}{l}\text { Fecal samples - Kelp gulls } \\
\text { penguin (Wild Animal) }\end{array}$ & $50(5)$ & E. coli & Incl2 & ST101 and ST744 & ISApl1-mcr-1 & (14) \\
\hline 2012-2018 & Argentina & $\begin{array}{l}\text { Urine, blood, other samples } \\
\text { (Human) }\end{array}$ & $192(192)$ & E. coli & $\begin{array}{l}\mathrm{IncH} 2 \\
\mathrm{IncX} 4\end{array}$ & $\begin{array}{l}\text { ST10, ST156, ST354, } \\
\text { ST8492, ST5208 }\end{array}$ & - & (37) \\
\hline 2013 & Bolivia & Potatoes (Food) & $83(1)$ & C. braakii & Incl2 & - & - & (16) \\
\hline 2013 & Argentina & $\begin{array}{l}\text { Fecal samples-Chicken } \\
\text { (Production Animals) }\end{array}$ & $10(10)$ & E. coli & Incl2 & $\begin{array}{l}\text { ST155 (CC10: ST10, } \\
\text { ST1141 and ST1286), } \\
\text { ST617, ST10, ST410, } \\
\text { ST1011, ST1408 }\end{array}$ & ISAp/1-mcr-1.5-pap2-ISAp/1 & (33) \\
\hline 2013-2014 & Ecuador & $\begin{array}{l}\text { Feces-chicken (Production } \\
\text { Animals) }\end{array}$ & $176(6)$ & E. coli & - & - & - & (24) \\
\hline 2013-2016 & Brazil & Meat Poultry (Food) & $60(2)$ & $\begin{array}{l}\text { Salmonella enterica serovar } \\
\text { Schwarzengrund }\end{array}$ & $\operatorname{lncX} 4$ & ST96 & $\begin{array}{l}\text { par } A \text { and hypothetical protein } \\
\text { upstream } m c r-1 \text { and pap2 } \\
\text { downstream }\end{array}$ & (44) \\
\hline 2013-2017 & Chile & Urine (Human) & $13(1)$ & E. coli & Incl2 & ST4204 (CC10) & $\begin{array}{l}\text { mcr-1 was delimited upstream } \\
\text { by a gene that encodes a pap2 } \\
\text { protein and downstream by a } \\
\text { relaxase-encoding gene (nikB) }\end{array}$ & (18) \\
\hline 2014 & Argentina & $\begin{array}{l}\text { Clinical samples - dogs and } \\
\text { cats (Pets) }\end{array}$ & $54(1)$ & E. coli & Incl2 & ST770 & $\begin{array}{l}m c r-1 \text { was delimited upstream } \\
\text { by nikB gene which encodes a } \\
\text { relaxase and pap2 downstream }\end{array}$ & (31) \\
\hline 2014-2017 & Brazil & Pork carcasses (Food) & $490(8)$ & $\begin{array}{l}\text { S. enterica serovar } \\
\text { Typhimurium }\end{array}$ & $\operatorname{IncX} 4$ & $\begin{array}{l}\text { ST19 } \\
\text { ST4556 } \\
\text { ST50 }\end{array}$ & $\begin{array}{l}m c r-1 \text { was delimited upstream } \\
\text { by IS26 and hypothetical protein } \\
\text { and pap2 downstream }\end{array}$ & (26) \\
\hline 2015 & Venezuela & $\begin{array}{l}\text { Fecal samples (Human and } \\
\text { Animal) }\end{array}$ & $93(2)$ & E. coli & Incl2 & ST452 and ST19 & Absence of ISAp/1 & (23) \\
\hline 2015 & Mexico & $\begin{array}{l}\text { Swine stool samples } \\
\text { (Production Animal) }\end{array}$ & $1(1)$ & E. coli & Incp0111 & ST744 & ISAp/1 upstream mcr-1 gene & (22) \\
\hline
\end{tabular}




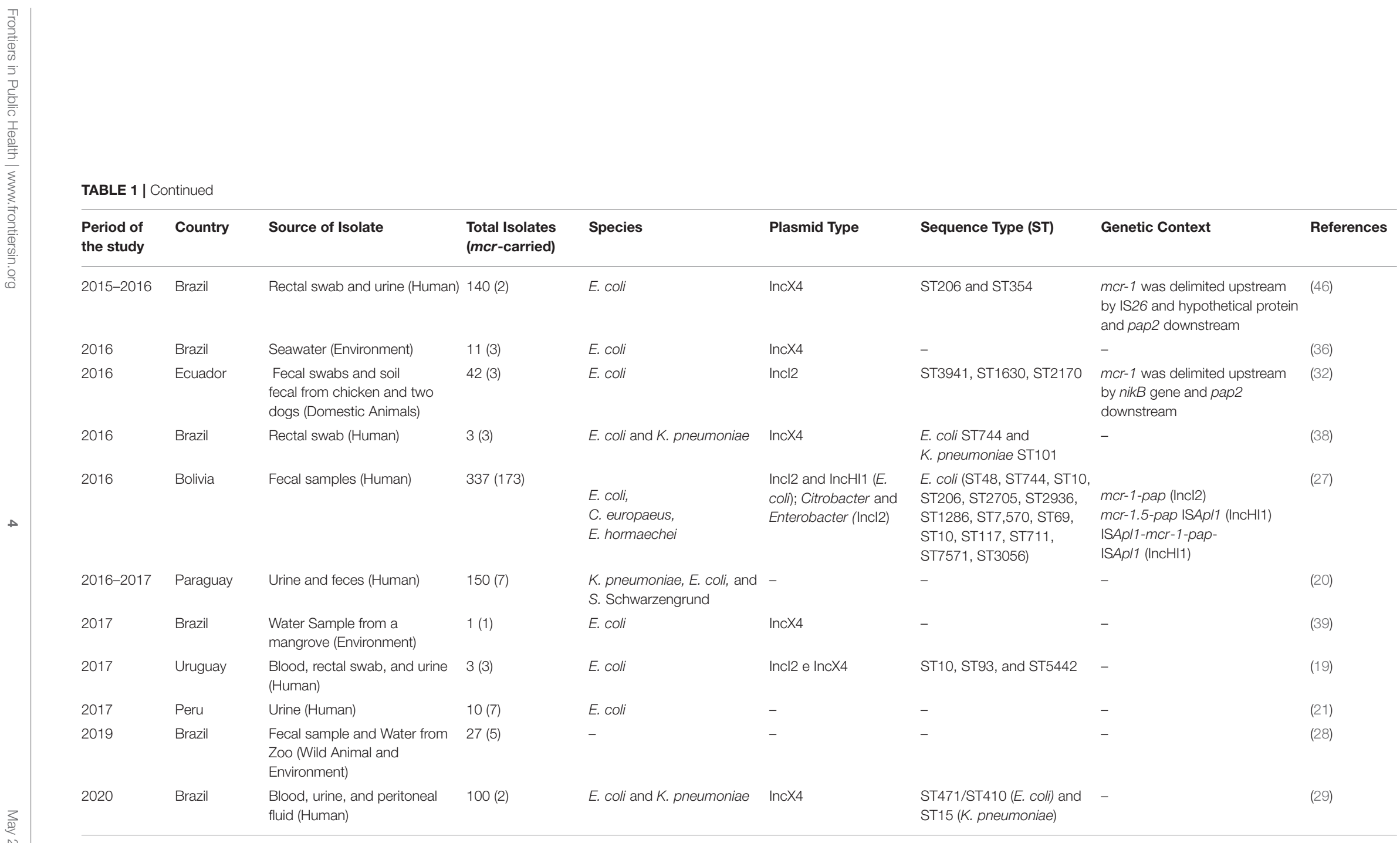

-: No data. 
IncX3-X4 hybrid, IncH1, IncHI1, IncHI2, IncP, IncI2, IncF, IncFII, an IncI2-IncFIB hybrid, and IncY (5). The $m c r-1$ gene can also be integrated into the chromosome of some strains (17). However, in Latin America, only four plasmids have been described so far: IncX4 (36), IncP (22), IncI2 (31), and IncHI2 (37), of which the IncX4 plasmid is the most frequent in Brazil $(38,39)$ (Table 1). There is a clear association between the IncX4 plasmids and the insertion sequences associated with the dissemination of the $m c r-1$ gene (40).

Plasmid analysis has revealed that the insertion sequence ISApl1 (which belongs to the IS30 family transposase), in a composite transposon (ISApl1-mcr-1-ISApl1), is usually present in IncHI2-type plasmids (size of $200 \mathrm{~kb}$ ), being either present or absent in IncI2-type plasmids $(60 \mathrm{~kb})$, and completely absent in IncX4-type plasmids (30 kb) (Table 1).

The role of ISApl1 in the mobilization of the $m c r-1$ gene was demonstrated in vitro by transposition. It was suggested that the recombination events associated with mobilization of the $\mathrm{mcr}$ 1 gene were initially mediated by two copies of ISApl1 from an unknown progenitor to a plasmid and subsequently transferred to Enterobacterales (41).

Besides that, according to Snesrud et al., the presence of a single or two copies of ISApl1 indicates a recent acquisition of the $m c r-1$ gene, whereas the absence of this insertion sequence could be correlated with the adaptation of the $m c r-1$ gene to a new host (41).

The regulation mechanism of $m c r-1$ gene expression is complex and remains unknown. In general, the gene expression is controlled by its promoter and the corresponding activators and/or inhibitors. Zhang et al. suspect that genes encoding activators and/or inhibitors in the host chromosome may affect the expression of the $m c r-1$ gene found on plasmids IncX 4 and other plasmids. They may vary expressively in unlike genetic backgrounds of the different strains and/or mcr-1harboring plasmids, despite that their promoters are remarkably similar (42).

Although the mobility and dissemination of the $m c r-1$ gene are associated with ISApl1 and the pap2 gene in most plasmid types (43), the genetic context of the IncX4 plasmid type, in Latin America, is different. This context is characterized by lacking the ISApl1, but it preserves the pap2 sequence and a hypothetical protein (hp) around the $m c r-1$ gene $(26,44)$. What would be the explanation for that?

Snesrud et al. analyzed the genetic environment of the $m c r-1$ gene associated or not with ISApl1 and concluded that the target site duplications generated by ISApl1 transposition are present even in lack of the ISApl1. This result suggests that the mechanism to mobilize the $m c r-1$ gene is the same as that observed in other plasmids, and after that, the loss of the insertion sequence by recombination events in IncX 4 occurs (45).

Furthermore, the IS26 mobile element upstream to the $\mathrm{mcr}$ 1 gene has been also associated with IncX4 plasmid types in Brazil, but there are no other reports in Latin America $(26,46)$ (Table 1). This Insertion Sequence (IS) plays an important role in the dissemination and evolution of the antimicrobial resistance genes on plasmids, including colistin resistance genes (1).

\section{DISCUSSION}

In veterinary medicine, colistin is mainly administrated in pigs and poultry production, for prophylaxis or treatment. The spread of colistin resistance may lead to treatment failure, as well as increase the pathogen transmission reach with quality and economic loss in production animals.

Strong scientific evidence indicates that the $m c r-1$ gene might have originated from animals because (i) colistin has been used extensively for decades in veterinary practices; (ii) $\mathrm{mcr}-1$ gene was largely identified in several animals and animal food products; (iii) the identification of the $m c r-1$ gene in $E$. coli isolate recovered before 1980 in China suggests that the emergence of this gene may be linked to the use of colistin as a growth promoter in the poultry industry; and (iv) genetic features of $m c r-1$ gene associated with ISApl1 were first identified in Actinobacillus pleuropneumoniae, a common animal pathogen (43), which could be involved in recombination events leading to the mobilization of the $m c r-1$ cassette.

Finally, a recent study has demonstrated that when colistin is banned from use in animal feed, there was a significant decrease of the $m c r-1$ gene prevalence in most sources, including pig farms, food, and environment samples (47). Given that the production animals can be a reservoir for $m c r-1$ gene and its dissemination can occur by food and environment, all countries should apply surveillance, monitoring, and restrictive measures to polymyxins use. In Latin America, Brazil, and Argentina (1) have already banned the use of colistin as a growth promoter, but the impact of this measure has not been evaluated yet.

The problem of antimicrobial resistance is related to the use and abuse of antibiotics in humans, animals, and the environment. Besides that, the $m c r-1$ gene is disseminated mainly by $E$. coli clones, with a high capacity to survive in different ecological niches, some of them with pandemic and epidemic potential. So, it seems clear that the One Health approach should be adopted to integrate veterinary and human medicine to address antimicrobial resistance.

\section{AUTHOR CONTRIBUTIONS}

SAML, TVD, and AFM: conception of the opinion, collected data, and wrote the paper. ALB and AFM: reviewed and edited. All authors contributed to the article and approved the submitted version.

\section{FUNDING}

This study was funded by National Institute of Antimicrobial Resistance Research - INPRA (MCTI/CNPq/CAPES/FAPs $\mathrm{n}^{\circ}$ 16/2014). SAML were supported by a grant from the Coordenação de Aperfeiçoamento de Pessoal de Nível Superior (CAPES). 


\section{REFERENCES}

1. Anyanwu MU, Jaja IF, Nwobi OC. Occurrence and characteristics of mobile colistin resistance ( $M c r)$ gene-containing isolates from the environment: a review. Int J Environ Res Public Health. (2020) 17:1028. doi: 10.3390/ijerph17031028

2. Olaitan AO, Morand S, Rolain J-M. Mechanisms of polymyxin resistance: acquired and intrinsic resistance in bacteria. Front Microbiol. (2014) 5:643. doi: 10.3389/fmicb.2014.00643

3. Kai J, Wang S. Recent progress on elucidating the molecular mechanism of plasmid-mediated colistin resistance and drug design. Int Microbiol. (2020) 23:355-66. doi: 10.1007/s10123-019-00112-1

4. Li Z, Cao Y, Yi L, Liu J-H, Yang Q. Emergent polymyxin resistance: end of an Era? Open forum Infect Dis. (2019) 6:ofz368. doi: 10.1093/ofid/ofz368

5. Quiroga C, Nastro M, Di Conza J. Current scenario of plasmid-mediated colistin resistance in Latin America. Rev Argent Microbiol. (2019) 51:93100. doi: 10.1016/j.ram.2018.05.001

6. Shen Z, Wang Y, Shen Y, Shen J, Wu C. Early emergence of $m c r-1$ in Escherichia coli from food-producing animals. Lancet Infect Dis. (2016) 16:293. doi: 10.1016/S1473-3099(16)00061-X

7. Wang C, Feng Y, Liu L, Wei L, Kang M, Zong Z. Identification of novel mobile colistin resistance gene mcr-10. Emerg Microbes Infect. (2020) 9:508-16. doi: 10.1080/22221751.2020.17 32231

8. Shen Y, Zhang R, Schwarz S, Wu C, Shen J, Walsh TR, et al. Farm animals and aquaculture: significant reservoirs of mobile colistin resistance genes. Environ Microbiol. (2020) 22:2469-84. doi: 10.1111/1462-2920.14961

9. Martins-Sorenson N, Snesrud E, Xavier DE, Cacci LC, Iavarone AT, McGann $\mathrm{P}$, et al. A novel plasmid-encoded $m c r-4.3$ gene in a colistin-resistant Acinetobacter baumannii clinical strain. J Antimicrob Chemother. (2020) 75:60-4. doi: 10.1093/jac/dkz413

10. Caselli E, D'Accolti M, Soffritti I, Piffanelli M, Mazzacane S. Spread of $m c r-1$ driven colistin resistance on hospital surfaces, Italy. Emerg Infect Dis. (2018) 24:1752-3. doi: 10.3201/eid2409.171386

11. Sherry N, Howden B. Emerging gram negative resistance to lastline antimicrobial agents fosfomycin, colistin and ceftazidime-avibactamepidemiology, laboratory detection and treatment implications. Expert Rev Anti Infect Ther. (2018) 16:289-306. doi: 10.1080/14787210.2018.1453807

12. Mendes Oliveira VR, Paiva MC, Lima WG. Plasmid-mediated colistin resistance in Latin America and Caribbean: a systematic review. Travel Med Infect Dis. (2019) 31:101459. doi: 10.1016/j.tmaid.2019.07.015

13. Rapoport M, Faccone D, Pasteran F, Ceriana P, Albornoz E, Petroni A, et al. First description of $m c r-1$-mediated colistin resistance in human infections caused by Escherichia coli in Latin America. Antimicrob Agents Chemother. (2016) 60:4412-3. doi: 10.1128/AAC.00573-16

14. Liakopoulos A, Mevius DJ, Olsen B, Bonnedahl J. The colistin resistance mcr-1 gene is going wild. J Antimicrob Chemother. (2016) 71:23356. doi: $10.1093 / \mathrm{jac} / \mathrm{dkw} 262$

15. Fernandes MR, Moura Q, Sartori L, Silva KC, Cunha MP, Esposito F, et al. Silent dissemination of colistin-resistant Escherichia coli in South America could contribute to the global spread of the mcr-1 gene. Eurosurveillance. (2016) 21:30214. doi: 10.2807/1560-7917.ES.2016.21.17.30214

16. Sennati S, Di Pilato VD, Riccobono E, Maggio TD, Villagran AL, Pallecchi $\mathrm{L}$, et al. Citrobacter braakii carrying plasmidborne $\mathrm{mcr}-1$ colistin resistance gene from ready-to-eat food from a market in the Chaco region of Bolivia. $J$ Antimicrob Chemother. (2017) 72:2127-9. doi: 10.1093/jac/dkx078

17. Saavedra SY, Diaz L, Wiesner M, Correa A, Arévalo SA, Reyes J, et al. Genomic and molecular characterization of clinical isolates of enterobacteriaceae harboring $\mathrm{mcr}$ - 1 in Colombia, 2002 to 2016. Antimicrob Agents Chemother. (2017) 61:e00841-17. doi: 10.1128/AAC.00841-17

18. Gutiérrez C, Zenis J, Legarraga P, Cabrera-Pardo JR, García P, Bello-Toledo $\mathrm{H}$, et al. Genetic analysis of the first $m c r-1$ positive Escherichia coli isolate collected from an outpatient in Chile. Brazil J Infect Dis. (2019) 23:2036. doi: 10.1016/j.bjid.2019.05.008

19. Papa-Ezdra R, Grill Diaz F, Vieytes M, García-Fulgueiras V, Caiata L, Ávila P, Brasesco M, et al. First three Escherichia coli isolates harbouring mcr-1 in Uruguay. J Glob Antimicrob Resist. (2020) 20:18790. doi: 10.1016/j.jgar.2019.07.016
20. Melgarejo Touchet N, Martínez M, Franco R, Falcón M, Busignani S, Espínola C, et al. Plasmid-mediated colistin resistance gene $\mathrm{mcr}-1$ in Enterobacteriaceae in Paraguay. Rev Salud Publica Del Paraguay. (2018) 8:44-8. doi: 10.18004/rspp.2018.junio.44-48

21. Ugarte Silva RG, Olivo López JM, Corso A, Pasteran F, Albornoz E, Sahuanay Blácido ZP. Resistencia a colistín mediado por el gen $m c r-1$ identificado en cepas de Escherichia coli y Klebsiella pneumoniae. Primeros reportes en el Perú. An Fac Med. (2018) 79:213. doi: 10.15381/anales.v79i3.15313

22. Garza-Ramos U, Tamayo-Legorreta E, Arellano-Quintanilla DM, RodriguezMedina N, Silva-Sanchez J, Catalan-Najera J, et al. Draft genome sequence of a multidrug- and colistin-resistant mor-1-producing Escherichia coli isolate from a swine farm in Mexico. Genome Announc. (2018) 6:e0010218. doi: 10.1128/genomeA.00102-18

23. Delgado-Blas JF, Ovejero CM, Abadia-Patiño L, Gonzalez-Zorn B. Coexistence of $m c r-1$ and blaNDM-1 in Escherichia coli from Venezuela. Antimicrob Agents Chemother. (2016) 60:6356-8. doi: 10.1128/AAC.01319-16

24. Vinueza-Burgos C, Ortega-Paredes D, Narváez C, De Zutter L, Zurita J. Characterization of cefotaxime resistant Escherichia coli isolated from broiler farms in Ecuador. PLoS ONE. (2019) 14:e0207567. doi: 10.1371/journal.pone.0207567

25. Associação Brasileira de Proteína Animal. Relatório Anual. (2020). Available online at: http://abpa-br.org/wp-content/uploads/2020/05/abpa_relatorio_ anual_2020_portugues_web.pdf (accessed November 20, 2020).

26. Rau RB, De Lima-Morales D, Wink PL, Ribeiro AR, Barth AL. Salmonella enterica $m c r-1$ positive from food in Brazil: detection and characterization. Foodborne Pathog Dis. (2020) 17:202-8. doi: 10.1089/fpd.2019.2700

27. Giani T, Sennati S, Antonelli A, Di Pilato V, di Maggio T, Mantella A, et al. High prevalence of carriage of $m c r$-1-positive enteric bacteria among healthy children from rural communities in the Chaco region, Bolivia, september to october 2016. Euro Surveill. (2018) 23:1800115. doi: 10.2807/1560-7917.ES.2018.23.45.1800115

28. dos Santos LDR, Furlan JPR, Ramos MS, Gallo IFL, de Freitas LVP, Stehling EG. Co-occurrence of $m c r-1, m c r-3, m c r-7$ and clinically relevant antimicrobial resistance genes in environmental and fecal samples. Arch Microbiol. (2020) 202:1795-800. doi: 10.1007/s00203-020-01890-3

29. Rocha IV, dos Santos Silva N, das Neves Andrade CA, de Lacerda Vidal CF, Leal NC, Xavier DE. Diverse and emerging molecular mechanisms award polymyxins resistance to Enterobacteriaceae clinical isolates from a tertiary hospital of Recife, Brazil. Infect Genet Evol. (2020) 85:104584. doi: 10.1016/j.meegid.2020.104584

30. Faccone D, Martino F, Albornoz E, Gomez S, Corso A, Petroni A. Plasmid carrying $\mathrm{mcr}$-9 from an extensively drug-resistant NDM-1-producing Klebsiella quasipneumoniae subsp. quasipneumoniae clinical isolate. Infect Genet Evol. (2020) 81:104273. doi: 10.1016/j.meegid.2020.104273

31. Rumi M V, Mas J, Elena A, Cerdeira L, Muñoz ME, Lincopan N, et al. Cooccurrence of clinically relevant $\beta$-lactamases and MCR-1 encoding genes in Escherichia coli from companion animals in Argentina. Vet Microbiol. (2019) 230:228-34. doi: 10.1016/j.vetmic.2019.02.006

32. Loayza-Villa F, Salinas L, Tijet N, Villavicencio F, Tamayo R, Salas S, et al. Diverse Escherichia coli lineages from domestic animals carrying colistin resistance gene mcr-1 in an Ecuadorian household. J Glob Antimicrob Resist. (2020) 22:63-7. doi: 10.1016/j.jgar.2019.12.002

33. Dominguez JE, Faccone D, Tijet N, Gomez S, Corso A, Fernández-Miyakawa $\mathrm{ME}$, et al. Characterization of Escherichia coli carrying mor-1-plasmids recovered from food animals from Argentina. Front Cell Infect Microbiol. (2019) 9:41. doi: 10.3389/fcimb.2019.00041

34. Manges AR, Harel J, Masson L, Edens TJ, Portt A, Reid-Smith RJ, et al. Multilocus sequence typing and virulence gene profiles associated with Escherichia coli from human and animal sources. Foodborne Pathog Dis. (2015) 12:302-10. doi: 10.1089/fpd.2014.1860

35. Chen P-A, Hung C-H, Huang P-C, Chen J-R, Huang I-F, Chen W-L, et al. Characteristics of CTX-M extended-spectrum $\beta$-lactamase-producing Escherichia coli strains isolated from multiple rivers in Southern Taiwan. Appl Environ Microbiol. (2016) 82:1889-97. doi: 10.1128/AEM.03222-15

36. Fernandes MR, Sellera FP, Esposito F, Sabino CP, Cerdeira L, Lincopan N. Colistin-resistant mcr-1-positive Escherichia coli on public beaches, an infectious threat emerging in recreational waters. Antimicrob Agents Chemother. (2017) 61:e00234-17. doi: 10.1128/AAC.00234-17 
37. Faccone D, Rapoport M, Albornoz E, Celaya F, De Mendieta J, De Belder D, et al. Plasmidic resistance to colistin mediated by $m c r-1$ gene in Escherichia coli clinical isolates in Argentina: a retrospective study, 2012-2018. Rev Panam Salud Pub. (2020) 44:e55. doi: 10.26633/RPSP.2020.55

38. Perdigão Neto LV, Corscadden L, Martins RCR, Nagano DS, Cunha MPV, Neves PR, et al. Simultaneous colonization by Escherichia coli and Klebsiella pneumoniae harboring mcr-1 in Brazil. Infection. (2019) 47:661-4. doi: 10.1007/s15010-019-01309-2

39. Sacramento AG, Fernandes MR, Sellera FP, Muñoz ME, Vivas R, Dolabella SS, et al. Genomic analysis of MCR-1 and CTX-M-8 co-producing Escherichia coli ST58 isolated from a polluted mangrove ecosystem in Brazil. J Glob Antimicrob Resist. (2018) 15:288-9. doi: 10.1016/j.jgar.2018.10.024

40. Sun J, Fang L-X, Wu Z, Deng H, Yang R-S, Li X-P, et al. Genetic analysis of the IncX4 plasmids: implications for a unique pattern in the $m c r-1$ acquisition. Sci Rep. (2017) 7:424. doi: 10.1038/s41598-017-00095-x

41. Snesrud E, He S, Chandler M, Dekker JP, Hickman AB, McGann P, et al. A model for transposition of the colistin resistance gene $m c r-1$ by ISApl1. Antimicrob Agents Chemother. (2016) 60:6973-6. doi: 10.1128/AAC.01457-16

42. Zhang H, Miao M, Yan J, Wang M, Tang Y-W, Kreiswirth BN, et al. Expression characteristics of the plasmid-borne $\mathrm{mcr}$ - 1 colistin resistance gene. Oncotarget. (2017) 8:107596-602. doi: 10.18632/oncotarget.22538

43. Poirel L, Kieffer N, Nordmann P. In vitro study of ISApll-mediated mobilization of the colistin resistance gene mcr-1. Antimicrob Agents Chemother. (2017) 61:e00127-17. doi: 10.1128/AAC.00127-17

44. Moreno LZ, Gomes VTM, Moreira J, de Oliveira CH, Peres BP, Silva APS, et al. First report of mcr-1-harboring Salmonella enterica serovar Schwarzengrund isolated from poultry meat in Brazil. Diagn Microbiol Infect Dis. (2019) 93:376-9. doi: 10.1016/j.diagmicrobio.2018.10.016

45. Snesrud E, McGann P, Chandler M. The birth and demise of the ISApl1-mcr1-ISApl1 composite transposon: the vehicle for transferable colistin resistance. MBio. (2018) 9:e02381-17. doi: 10.1128/mBio.02381-17

46. Zamparette CP, Schorner M, Campos E, Moura Q, Cerdeira L, Tartari DC, et al. IncX4 plasmid-mediated mcr-1.1 in polymyxin-resistant Escherichia coli from outpatients in Santa Catarina, Southern Brazil. Microb Drug Resist. (2020) 26:1326-33. doi: 10.1089/mdr.2019.0203

47. Wang Y, Xu C, Zhang R, Chen Y, Shen Y, Hu F, et al. Changes in colistin resistance and $m c r-1$ abundance in Escherichia coli of animal and human origins following the ban of colistin-positive additives in China: an epidemiological comparative study. Lancet Infect Dis. (2020) 20:116171. doi: 10.1016/S1473-3099(20)30149-3

Conflict of Interest: The authors declare that the research was conducted in the absence of any commercial or financial relationships that could be construed as a potential conflict of interest.

Copyright (C) 2021 Lentz, Dalmolin, Barth and Martins. This is an open-access article distributed under the terms of the Creative Commons Attribution License (CC BY). The use, distribution or reproduction in other forums is permitted, provided the original author(s) and the copyright owner(s) are credited and that the original publication in this journal is cited, in accordance with accepted academic practice. No use, distribution or reproduction is permitted which does not comply with these terms. 